\title{
The '16+1' Framework and China-EU Cooperation in the Western Balkans: A Region Building Perspective
}

\author{
Shaohua Yan ${ }^{1}$ \\ Guangdong University of Foreign Studies \\ shaohua.yan@gdufs.edu.cn
}

\begin{abstract}
This paper adopts a region-building perspective to shed light on the nature of the $16+1$ framework and elucidates what it means for EU-China cooperation in the Western Balkans. By comparing the 16+1 framework with the European approach to region-building in the Western Balkans, the paper argues that the Chinese and European approaches towards the Western Balkans are largely complementary rather than competitive as China's engagement works to facilitate the EU's agenda in the region. The 'outside-in' perspective brought about by China via the 16+1 framework could contribute to regionbuilding in the Western Balkans and the EU and China could jointly move forward the next stage of European integration.
\end{abstract}

Key Words: EU; China; 16+1; Western Balkans; Region-building; Cooperation

Since its initiation in 2012, the ' $16+1$ ' framework has injected further impetus in strengthening relations between China and the Central and Eastern European (CEE) countries, making China a new but important economic and political player in the region. Although there are variations in terms of their level of participation and perception, the CEE countries have been generally positive towards participating in the $16+1$ cooperation as it brings not only trade and investment opportunities, but also development potential for CEE countries (Long, 2016). For countries in the CEE region, the 16+1 framework was welcomed with great hopes as it represented a rare opportunity as they would otherwise not have had the chance to do business with China (Budeanu, 2018). In cash-strapped countries such as Poland, the $16+1$ framework aroused initial interest in attracting Chinese capital and know-how in infrastructure building (Tuszyński, 2015).

However, the $16+1$ framework has also met with various challenges from both the EU and the CEE countries over the past years. As the 16+1 framework includes $11 \mathrm{EU}$ member states and 5 Balkan countries, the EU is concerned with the initiative's impacts on the EU's internal cohesion which is perceived to be undermined by Beijing's attempts to 'divide and rule' via cooperating with some CEE countries (Stanzel, 2016). As China's influence grows in the CEE region, the EU fears that the 16+1 framework

\footnotetext{
${ }^{1}$ This paper was accepted by the $5^{\text {th }}$ China-CEE High Level Think Tank Forum, Panel 3 'Strengthening China-EU Cooperation in the 16+1 Framework', 2018.
} 
'could become a Trojan horse for China to shatter the bloc's unity in sensitive areas ranging from the single market to foreign investment vetting' (Peel, 2018).

This paper contends that the EU's concerns partly come from a lack of understanding of the nature of the 16+1 framework, and that the Chinese side also has a responsibility to provide further clarification. In order to bridge the gap between the two sides, this paper seeks to understand the $16+1$ framework from the perspective of region-building practices, and elucidates what this perspective means for EU-China cooperation in the Western Balkans. Region building in this paper is broadly understood as the practices of 'increasing economic, political, social, or cultural interactions among geographically or culturally contiguous states or societies' (Börzel \& Risse, 2016, p. 8). This perspective allows us to go beyond the 'divide and rule' discourse and comprehend the real nature of the $16+1$ framework in an innovative way.

There is a rich literature on the EU's relations with the Western Balkans, largely focusing on the enlargement process (Anastasakis, 2008; Belloni, 2009; Elbasani, 2008, 2013; Noutcheva, 2009) or Russia's role in the region (Bieri, 2015; Nelaeva \& Semenov, 2016), with little reference to the 16+1 framework that has important implications for EU-Western Balkan relations. Scholarly research on China-Western Balkan relations has also been growing due to the advancement of the $16+1$ framework (Jacimovic, Dragutinović Mitrović, Bjelić, Tianping, \& Rajkovic, 2018; Tonchev, 2017), yet the EU's dimension has not been taken into account in such literature. When it comes to region building, the literature has been dominated by what Amitav Acharya called a 'EU-centrism', a tendency to 'judge other regionalisms in terms of a benchmark that draws heavily from the EU's institutions and process, while ignoring other possible approaches to regionalism and refusing to view their performance in terms of the goals set by themselves' (Acharya, 2016, p. 109). This article contributes to the literature by conducting comparative research on and using synergies between the European and Chinese approach to region building in the Western Balkans, thereby highlighting China's contributions to region building practices in an area that is dominated by the EU.

As the Western Balkans are in the accession process with the EU, the ' $16+1$ ' framework also has to consider its compatibility with EU policies towards the region. As such, this paper takes the view that the Western Balkans should take priority in EU-China cooperation under the $16+1$ initiative because the EU is less sensitive on the issue of unity here and there is potential for cooperation on both sides. In fact, due to the complexity of the situation of EU members of the CEE, China has recently devoted much attention to non-EU members in the Western Balkans (Serbia in particular) under the 16+1 framework (Song, 2018).

The importance of the Western Balkans on the agenda of the EU has also been highlighted by the intensification of the EU's engagement with the Western Balkans in recent years, which was partly driven by the progress of the $16+1$ framework. Some observers assumed in 2015 that the need to shield from China's influence could serve to expedite EU enlargement activity towards the Western Balkans (Burnay, Raube, \& Wouters, 2015), a scenario that has largely come true in recent years. In response to China's increasing clout in the Western Balkans, the EU has stepped up its engagement with the region by launching the Berlin Process in 2014, which brought a positive momentum for regional cooperation and new impetus for the enlargement process 
(Lilyanova, 2016). In 2018, the EU also adopted a new enlargement strategy to enhance its engagement with the Western Balkans (EU Commission, 2018).

In this context, this paper conducts in-depth research into the EU's policies towards the Western Balkans and China's 16+1 framework, and compares the two approaches in the context of region-building with a view to identify potential synergies and cooperation between the EU and China in the Western Balkans.

\section{The 16+1 Framework: One Framework, Two Sub-Regions, Many Challenges}

Established as a result of Chinese Premier Wen Jiabao's visit to Poland in 2012, the 16+1 framework has undergone significant developments, giving rise to heated discussions in policy circles and numerous projects on the ground. In practice, the $16+1$ framework serves as a platform for economic and cultural cooperation between the 16 $\mathrm{CEE}$ countries and China. However, the nature of the $16+1$ framework remains ambiguous to many observes. The $16+1$ framework is originally a Chinese idea and remains mostly promoted by China, even though CEE countries are increasingly engaging with it. But if we examine the discourse from both sides, it is obvious that there is a lack of a coherent label for the $16+1$ framework. Scholarly articles and official documents have made references to the $16+1$ mechanism as a number of concepts that could be used interchangeably, such as 'framework', 'format', 'formula', 'dialogue', 'regional cooperation' or 'cooperation platform' etc. This has created certain ambiguity when it comes to capturing the nature and characteristics of the initiative.

In an attempt to address the ambiguities, Professor Kong Tianping from the Chinese Academy of Social Science provided an authoritative account of the genesis and characteristics of the $16+1$ framework. He outlined five main characteristics of the $16+1$ framework, including equal partnership; loose institutionalisation; comprehensiveness of cooperation; multifunctional arrangement; and a well-planned framework (Kong, 2015). But still this characterisation does not provide a comprehensive account of the nature of the initiative and its future direction. As a matter of fact, a lack of clarity and understanding of the nature of the $16+1$ cooperation is part of the source of suspicions and criticism surrounding the framework itself.

This paper considers the $16+1$ framework as an institutionalised inter-governmental framework for regional cooperation between China and CEE countries. The 16+1 framework is regarded by some as a 'breakthrough' and 'real novelty' that signaled 'a new way of thinking' in China's policy towards the CEE countries (Kong, 2015). But in terms of its nature, $16+1$ is not something new as it reflects existing practices that China had adopted previously. The fact that 16 CEE countries are put under one framework could be better understood in the broader context of China's evolving approach to deal with external relations on a regional basis. Prior to the $16+1$ framework, a regional approach has obviously been manifest in China's relations with Africa and Latin America, with the Forum on China-Africa Cooperation (FOCAC) and the ChinaCommunity of Latin American and Caribbean States Forum playing a central role respectively. The same regional approach has also been adopted to develop relations with Southeast Asian countries (via ASEAN) and Central Asian countries (via Shanghai Cooperation Organization). 
In the case of dealing with CEE countries, the reasons for China to take a regional approach are two-fold: first, there is a historical reason to group the CEE countries in one framework as they belong to the former Soviet camp and enjoy a traditionally friendly relationship with China. Secondly, there is a practical reason to regroup the CEE countries as China is used to dealing with countries in the same region on a group basis, which provides convenience and efficiency for China's diplomacy (Song, 2018, p. 759).

However, there are inherent problems in China's approach to put the CEE countries under one framework. As Professor Liu Zuokui pointed out 'CEE is a nonhomogeneous region and hard to form a strategic entity' (Liu, 2013). While the term CEE provides a certain convenience for conceptual and analytical purpose, in practice one could identify a number of dividing lines within the CEE countries (geographic location, size, language, development level, EU membership etc.), with the most important dividing line being the EU membership. Relationship with the EU has apparently split the CEE countries into two distinct sub-groupings: EU and non-EU members, the latter points to countries in the Western Balkans. This cleavage has impeded CEE countries from forming 'an integral strategic power' and presents China with significant challenges in approaching the CEE as an integral part. In view of this challenge, it makes more sense to examine China's cooperation with the sub-groupings within the $16+1$ framework. This paper investigates the EU's and China's approach to the Western Balkans from the perspective of region-building.

\section{The Western Balkans in the 16+1 Framework: between China and the EU}

A particular sub-grouping within the $16+1$ framework is the Western Balkans, a term coined by EU policy makers in the 1990 s to describe 'ex-Yugoslavia, minus Slovenia, plus Albania' (Vangeli, 2016, p. 46). Croatia was originally included in this subgrouping but was eliminated after its accession to the EU in 2013. Geographically, Kosovo is also part of the 'Western Balkans', but as China does not recognise Kosovo's independence, it is also excluded from the $16+1$ framework. There are hence five Western Balkan countries engaged in the 16+1 framework, including Albania, BosniaHerzegovina, Macedonia, Montenegro, and Serbia.

As Western Balkan countries are all (potential) candidates at different stages of the accession process, they are naturally oriented towards the EU in their external relations. For the Western Balkans, the EU stands out as the leading investor and trading partner, accounting for over $76 \%$ of the region's total trade (Commission, 2017). However, the Western Balkans' relationship with the EU is not without contention, one that is rife with political discord. Although the Western Balkans are in the accession process with the EU, Anastas Vangeli pointed out that, ironically, 'what defines the Western Balkans as a concept is precisely the fact that these countries are not members of the European Union' (Vangeli, 2016, p. 46). This for the Balkan countries has created a duality of hope and frustration towards the EU: on the one hand, the prospect of EU accession raises expectations and works as an influential tool to engage Balkan countries; on the other hand, the conditionality associated with EU membership means that the reforms required by the EU take time and might run counter to the immediate or mid-term needs of the Western Balkans, thus creating a sense of frustration that accession is not likely in the foreseeable future. This duality, coupled with the impacts of the global financial crisis that has restrained the EU's 
investments in the region, has prompted the Western Balkans to look for alternative, complementary partners.

China stands out as such an alternative partner with the initiation of the $16+1$ framework. For the Western Balkans, cooperation with China is not only less contentious, but there is also an inter-party consensus on the importance of cooperating with China for two major reasons: first, there is a need to develop their infrastructure and attracting foreign investments to boost the economy, however, there are only limited EU funds available due to fact that the Western Balkans have not yet joined the EU; second, there is also the political will from the leaders in the region to pursue closer relations with China as the ability to promote international cooperation and to attract foreign investments translates into domestic political legitimacy (Vangeli, 2016, p. 47). The fact that China is willing to re-imagine the region as a land bridge with untapped economic potential has particularly struck a chord among Western Balkan countries which would have otherwise been portrayed as 'an exceptionally scary and dysfunctional periphery' (Vangeli, 2016, p. 47). Interestingly, from a strategic perspective, engaging with China in the $16+1$ framework also serves as a way for the Western Balkans to reduce their dependence on the EU while raising their visibility and leverage in Brussels (Hudak, 2017, p. 33).

\section{The EU's Approach to the Western Balkans in the Context of Region-Building}

The Western Balkans is a region of particular importance for the EU as it is located in the EU's immediate backyard. The conflicts in Kosovo and Bosnia in the 1990s provided an important impetus to the evolution of the EU's Common Foreign and Security Policy (CFSP) and the creation of the European Security and Defense Policy (CSDP) (Gross, 2007). The refugee crisis in recent years has further highlighted the importance of the Western Balkans for the EU's security and stability. On top of security concerns, there are also normative reasons for the EU to closely engage the countries in the Western Balkans, which has not only had 'a major defining impact on the image, nature and development of the EU's foreign policy', but has also become 'the site of the EU's most comprehensive structural foreign policy' (Keukeleire \& Delreux, 2014, p. 242). The EU thus maintains close links with the countries of the Western Balkans, and has become a dominant actor in the region wielding the full spectrum of its toolkit, including the CFSP and CSDP as well as Community instruments.

Following the Kosovo crisis in the 1990s, the EU established two political and economic processes with regard to the Western Balkans. First, the Stability Pact for South Eastern Europe was initiated in 1999 with the aim of establishing and reinforcing peace and security in South Eastern Europe (SEE). The Stability Pact offered the countries of the Western Balkans the perspective of membership in the Euro-Atlantic structures, and supported the countries of SEE in 'efforts and reforms aimed at sustainable peace, democratic development and economic well-being aimed at ensuring long-lasting stability to the region' (Farnesina, 2018). Bringing together more than 40 partner countries and international organisations, the Stability Pact represented a form of regional cooperation through which various parties participated in reinforcing peace and stability in the region. However, this more outside (EU)-driven initiative was replaced in 2008 by the Regional Cooperation Council (RCC) which is 'an all-inclusive, 
regionally owned and led cooperation framework' (RCC, 2017) that gives SEE countries more responsibility in the management of regional operations.

In parallel with the Stability Pact, the Stabilization and Association Process (SAP) was launched in 1999 and is still serving as one of the cornerstones of the EU's policy towards the Western Balkans. The SAP engages the Western Balkan countries in a progressive partnership aimed at eventual EU membership. It is based on four elements: contractual relationships (bilateral Stabilization and Association Agreements); trade relations (autonomous trade measure); financial assistance (the Instrument for Pre-accession); and regional cooperation and good neighbourly relations (Commission, 2016). The Thessaloniki European Council of 19-20 June 2003 reiterated the EU's determination to fully and effectively support the Western Balkans on their path towards European integration and ultimate EU membership (Council, 2003).

This prospect of accession gives the EU a unique leverage over the Western Balkans countries, which is reflected in the concept of conditionality that the EU put in place in the CEE countries' accession process. On top of the Copenhagen criteria, the EU has further added conditions in regard to the Western Balkans specific post-war situation, including commitments to peaceful resolution of conflicts, regional cooperation and good neighbourly relations. It is thus observable that the EU has adopted a larger regional approach to the Western Balkans. However, the EU's regional approach has been undermined by some inherent asymmetries: between the politico-security dimension and the economic dimension; between external EU demands and local economic needs; and between the regional and the bilateral dimension.

The EU applies a comprehensive and complex structural foreign policy towards the Western Balkans that involves many dimensions (political, security, socio-economic, legal) (Keukeleire \& Delreux, 2014, p. 243). Political mediation, stabilisation, economic cooperation, and legal harmonisation have thus become the focus of the EU's policy in the region. However, it is difficult for the EU to achieve the congruence and applicability of the different strategies of stabilisation, transformation and integration. Instead of pursuing stabilisation through integration, the EU has in practice prioritised stabilisation over integration (Tzifakis, 2007, p. 61). Ruth Turrion has shown that the EU's conditionality policies towards the Western Balkans have been more linked to political matters related to security and geopolitical needs, instead of the declared objective/technical criteria (Turrion, 2015). Othon Anastasakis also pointed out that security concerns often supersede all other considerations in the EU's conditionality approach (Anastasakis, 2008, p. 371). Although the EU has realised that a successful policy towards the Western Balkans must include Community instruments as well as CFSP/CSDP instruments, economic cooperation is yet to be strengthened in order to underpin the EU's dual policy of stabilisation and integration in the region.

Another asymmetry is the external EU demands and local economic needs. With various financial instruments and programmes at its disposal, the EU is by far the most important donor in the Western Balkans. Yet EU funds are largely perceived as very complex and lengthy from an administrative point of view (Hudak, 2017, p. 31). Moreover, the EU's conditionality on structural reforms also makes it slow to respond to local economic needs in the Western Balkans. The conditionality approach means that EU policy towards the region is essentially based on EU considerations and standards rather than local reality and needs. Notable examples are the EU's failure to 
grant funds to the Slovenian project of building a railway from the port of Koper to Divaca, and to the Croatian project to develop the port of Rijeka, projects that are thought to be important in developing infrastructure in the Western Balkans but which nevertheless failed to secure EU grants.

Last but not least, the EU's approach is also undermined by an asymmetry between the regional and the bilateral dimension. Within the Stabilization and Association Process, the EU emphasises regional cooperation and good neighbourly relations as 'essential for stability and the region's ongoing reconciliation process' (EEAS, 2017), yet the EU has been hesitant to elevate the SAP into a regional grand strategy due to contradictions in its policies. Instead of adopting a 'one package' approach to the region's integration, the EU has insisted on evaluating the Western Balkan countries' accession process on a one-by-one basis (Tzifakis, 2007). Consequently, the SAP has actually fostered bilateral cooperation between the EU and the individual Western Balkan countries, which might not be conducive to building regional economic and political cooperation. In fact, the very nature of enlargement has determined that the EU's approach towards the Western Balkans is more bilateral than regional. In line with the enlargement logic, the primary concern of Western Balkan countries is a bilateral relationship with Brussels rather than regional cooperation.

\section{China's Approach to the Western Balkans in the Context of Region-Building}

China embraces a somewhat different vision for the Western Balkans. On top of the historical reason, the $16+1$ framework and One Belt One Road initiative (OBOR) have injected new impetus into the China-Western Balkans relations in recent years. With the 16+1 framework, the Western Balkan countries have gained increasing importance not least because of the failure of China's first attempts to sell infrastructure projects to the EU members (Matura, 2017). But China's focus on the Western Balkans goes beyond a passive readjustment to this reality and reveals a more forward-looking mindset. For China, the Western Balkans occupy a strategic position in the broader China-Europe relations. Rather than portraying the Western Balkans as an unstable and backward periphery that needs to be 'fixed', China pictures the Western Balkans as a region with untapped economic potential and, more importantly, one that could serve as the bridgehead to tap into the European market. Valbona Zeneli notes that China's overall interest in the region:

Appears to go beyond markets-in fact, the Balkans market could be considered insignificant for trade. It also seems to go beyond the need to secure a source of commodities, although the Balkans are rich in natural resources. Rather it appears that China is focused on infrastructure and access to Western European markets (Zeneli, 2014).

Hence, China's engagement with the Western Balkans does not aim to 'divide and rule' Europe, but should be understood in the broader context of supporting the OBOR and contributing to the 'all-round and balanced growth of the China-EU Comprehensive Strategic Partnership'(China-CEEC, 2016). China is well aware of the European orientation of the Balkan states which are undergoing a fundamental transformation and Europeanisation, and there is no intention on the part of China to derail that process as China has made it clear repeatedly that its engagement with the CEE countries (including the Western Balkans) is aimed at "pushing the comprehensive, 
balanced development of China-EU relations'. It is for this reason that Professor Liu Zuokui defines China's approach as a 'regional approach' combined with 'European perspective' (Liu, 2013).

China's approach towards the Western Balkans is now mainly developed within the $16+1$ framework, which institutionalises a new form of regional cooperation. In terms of the institutional structure, the $16+1$ framework displays some common characteristics with the EU-China dialogue structure, which serves as partial evidence of the European perspective of China's engagement in the region. Under the $16+1$ framework, China's engagement with the Western Balkans is mainly based on three pillars: political dialogue; economic and trade cooperation; and cultural and peopleto-people exchanges. ${ }^{2}$ This has largely corresponded to the three-pillar structure of EU-China dialogue. ${ }^{3}$ However, China's approach towards the Balkans also bears some unique features compared to the EU's.

First of all, China's engagement is more economic/development-focused rather than political/security-focused. A close examination of the official documents signed under the 16+1 framework 'shows that relations between [China and CSEECs] are developing in an economic and transport-geographic direction, and not a political and geostrategic one'(Plevnik, 2016, p. 16). In line with its non-interventionist principle, China has chosen to circumvent the discussion on high-political and sovereign affairs, and focuses on low-political and economic affairs, which is considered to be one of the reasons behind China's 'more successful external approaches to the Balkans' (Vangeli, 2016, p. 47). This development-focused approach is particularly manifest in its heavy infrastructure investments in the region. The roads, railways, ports, bridges and other infrastructure projects that China invests in the Western Balkans form 'a part of a grand network of logistics that not only link Western Europe with South Europe via the Balkans, but also connects Europe with China' (Jian, 2017, p. 201). Therefore, China's approach not only serves its own ties with Europe, but also the Western Balkans' path towards better connection and integration with the EU.

Secondly, China's approach to the region is based on equal rather than hierarchical partnership. The EU's enlargement framework is fundamentally Brussels-centered, with Western Balkan states being categorised into hierarchical status of candidate countries or potential candidate countries in line with their progress in meeting the Copenhagen membership criteria. This sort of 'benchmarking' by the EU has actually created a sense of competition among Western Balkan countries, which risks undermining the Balkan regional solidarity and identity. In the $16+1$ framework, the Balkan states are treated equally in spite of their size, political maturity or development level. The equality and openness for agenda-setting within the $16+1$ framework means there is room for local ownership that is usually lacking in the EU's approach. It provides a rare opportunity for the Western Balkan countries to prioritise their concerns and jointly develop the agendas based on their own needs, which would otherwise be treated as low priority in the case of the EU. A notable example in this regard is the 2018 China-CEE summit in Sofia, during which China addressed the

\footnotetext{
${ }^{2}$ See the Suzhou Guidelines for Cooperation between China and Central and Eastern European Countries, retrieved 16 December 2018, http://www.china-ceec.org/eng/ldrhw_1/sz2015/hdxw/t1411473.htm 3 See EEAS, EU-China Dialogue Architecture, November 2015, retrieved 16 December 2018, https://eeas.europa.eu/delegations/china_en/18538/EU-China\%20Dialogue\%20Architecture
} 
concerns of the CEE countries regarding the issues of trade deficit, market access, invest environment, and level-playing field etc.(Szczudlik, 2018).

Thirdly, while China maintains bilateral relations with individual countries, the $16+1$ framework engages the Western Balkans on a regional basis. The EU also includes a regional approach towards the Western Balkans, but the SAP as its major policy instrument is essentially of a bilateral nature that has not succeeded in building regional economic and political cooperation as expected. It is undeniable that China has bilateral dealings and better cooperation with some Western Balkan countries, such as Serbia, yet the $16+1$ as China's major policy framework towards the region provides a multilateral platform to centralise communications and engage the region as a whole.

\section{Go Beyond the Zero-Sum Thinking: $16+1$ and EU-China Cooperation in the Western Balkan Region-Building}

This paper has sought to compare the EU and China's approach to the Western Balkans from a region-building perspective. Certainly, both the EU and China have their own specific interests in the Western Balkans, which largely explains the differences in their approaches. Yet regardless of the variations in their approaches, this paper does not aim to suggest that one is better than the other. Instead, the purpose is to demonstrate that each of the approaches has its own unique advantage and they do not have to be competing with each other. The EU focuses on political reform and security in the Western Balkans as part of the ongoing accession process, while China invests mainly on infrastructure building in the region as part of the broader strategy to build a gateway to Europe; the two approaches are therefore largely complementary at least in a short to medium term. In the longer term, there would be increasing convergences between European and Chinese interests as the growing Chinese investments cannot stay immune to political and security challenges in the region. There is thus ample room for both sides to cooperate in terms of region-building in the Western Balkans.

A region building perspective also serves to shed new light on both the EU and China's engagements in the Western Balkans. From a region-building perspective, China's engagement in the Western Balkans does not necessarily go against European unity and integration, but instead works to facilitate the EU's own agenda in the region in addition to bringing local economic benefits. If the 16+1 framework and the EU's enlargement policy are to succeed eventually in the Western Balkans, region-building stands out as a common challenge faced by both sides. It is thus imperative for the EU and China to go beyond zero-sum thinking, and work together on promoting regional cooperation which is in the interests of both European integration and the broader China-CEE (Europe) relations. In this regard, this paper puts forward the following recommendations for the consideration of both the EU and China.

First of all, region-building should be seen as a priority in both the EU and China's approach towards the Western Balkans. This entails that both the EU and China should think about how to fit their approach into regional integration and cooperation frameworks in the Western Balkans. For this purpose, a joint consultation mechanism between the two sides would facilitate the communication of each other's concerns and priorities while sharing experience and best practices in regional developments. And the joint consultation could take place either within the EU-China dialogue or within the $16+1$ framework if the EU is willing to participate in a substantial way. 
Secondly, if the EU is too reluctant to join consultation in a China-initiated $16+1$ framework, it is in the interest of the EU to involve China in its integrative mechanism in a way to take advantage of the China factor in shaping the next stage of European integration. In this sense, the Regional Cooperation Council (RCC), which aims to 'help prosperity and growth through regional action in SEE, while advancing European and Euro-Atlantic integration' (RCC, 2017), serves as another appropriate platform for EUChina consultation. Given that China is an increasingly important actor in the region and there are largely overlapping goals between RCC participants and 16+1 members, it makes good sense to involve China in the RCC so that China could think and do more in terms of regional cooperation and broader European integration.

Last but not least, the EU and China should work in close consultation with the Western Balkans to bring concrete results to regional development. The EU's political and security-centered approach and China's economic and development-centered approach could actually complement each other in the pursuit of common objectives in the region and ensure a balance between short-term and long-terms interest for both sides. In particular, the EU and China could seek to outline synergies in development of regional infrastructure and connectivity, given that there are actually common goals in the Western Balkans, the China-EU Connectivity Platform, the Tran-European Transport Network, and the 16+1 Framework. As the EU is the most advanced integration project that aims to integrate the Balkan regions as well, better connectivity and economic cooperation within the region would serve the EU's goals. Hence, it is advisable for the EU and China to jointly fund regional infrastructures in order to advance not only 'hard connectivity' but also 'soft connectivity' in the Western Balkans.

\section{Bibliography}

Acharya, A. (2016). Regionalism Beyond EU-Centrism. In T. A. Börzel \& T. Risse (Eds.), The Oxford Handbook of Comparative Regionalism. Oxford: Oxford University Press.

Anastasakis, O. (2008). The EU's political conditionality in the Western Balkans: towards a more pragmatic approach. Southeast European and Black Sea Studies, $8(4), 365-377$.

Belloni, R. (2009). European integration and the Western Balkans: lessons, prospects and obstacles. Journal of Balkan and Near Eastern Studies, 11(3), 313-331.

Bieri, M. (2015). The Western Balkans Between Europe and Russia. CSS Analysis in Security Policy, 170.

Börzel, T. A., \& Risse, T. (2016). Introduction: Framework of the Handbook and Conceptual Clarifications. In T. A. Börzel \& T. Risse (Eds.), The Oxford Handbook of Comparative Regionalism: Oxford University Press.

Budeanu, A. (2018). The 16+1 Platform: China Opportunities for Central and Eastern Europe. ASIA FOCUS (86), 1-15.

BURNAY, M., RAUBE, K., \& WOUTERS, J. (2015). China's Foreign Policy and External Relations. Retrieved from Brussels: 
China-CEEC. (2016). The Medium-Term Agenda for Cooperation between China and Central and Eastern European Countries. Retrieved from http://www.fmprc.gov.cn/mfa_eng/zxxx_662805/t1318038.shtml

Commission. (2016). Stabilisation and Association Process. Retrieved from https://ec.europa.eu/neighbourhood-enlargement/policy/glossary/terms/sap_en

Commission. (2017). Western Balkans: trade picture. Retrieved from http://ec.europa.eu/trade/policy/countries-and-regions/regions/western-balkans/

Commission. (2018). A credible enlargement perspective for and enhanced EU engagement with the Western Balkans. Retrieved from Strasbourg:

Council. (2003). Eu-Western Balkans Summit Thessaloniki, 21 June 2003 Declaration. (10229/o3 (Presse 163)). Thessaloniki: Council of the European Union.

EEAS. (2017). Western Balkans. Retrieved from https://eeas.europa.eu/headquarters/headquarters-homepage/7859/westernbalkans_en

Elbasani, A. (2008). EU enlargement in the Western Balkans: strategies of borrowing and inventing. Journal of Southern Europe and the Balkans, 1O(3), 293-307.

Elbasani, A. (2013). European integration and transformation in the Western Balkans: Europeanization or business as usual? : Routledge.

Farnesina. (2018). Regional Cooperation Council (former Stability Pact for South East Europe). Retrieved from http://www.esteri.it/mae/en/politica_estera/aree_geografiche/europa/ooii/patto_di_stabilit_dei_balcani.html

Gross, E. (2007). European Union Foreign Policy towards the Balkans. In N. Casarini \& C. Musu (Eds.), European foreign policy in an evolving international system: the road towards convergence. Basingstoke: Springer.

Hudak, H. (2017). '16+1': A Regional Cooperation Mechanism in the Heart of Europe. (Master), College of the Europe in Bruges, Bruges.

Jacimovic, D., Dragutinović Mitrović, R., Bjelić, P., Tianping, K., \& RaMaster M. (2018). The role of Chinese investments in the bilateral exports of new EU member states and Western Balkan countries. Economic research-Ekonomska istraživanja, 31(1), 1185-1197.

Jian, J. (2017). China's engagement in the Balkans: challenges and prospects from a geopolitical perspective. In W. Song (Ed.), China's Relations with Central and Eastern Europe: From" Old Comrades" to New Partners. London: Routledge.

Keukeleire, S., \& Delreux, T. (2014). The Foreign Policy of the European Union. Basingstoke: Palgrave Macmillan.

Kong, T. (2015). 16+1 Cooperation Framework: Genesis, Characteristics and Prospect. Retrieved from http://16plus1-thinktank.com/1/20151203/868.html 
Lilyanova, V. (2016). The Western Balkans' Berlin process: A new impulse for regional cooperation. Retrieved from Brussels: Liu, Z. (2013). The Pragmatic Cooperation between China and CEE: Characteristics, Problems and Policy Suggestions. Retrieved from Beijing:

Long, J. (2016). Opportunities and Challenges of the Belt and Road Initiative in Central and Eastern Europe (一带一路'倡议在中东欧地区的机遇和挑战, Yidai yilu changyi zai zhongdongou diqu de jiyu he tiaozhan). Guoji guancha, 3, 118-130.

Matura, T. (2017). Hungary and China relations. In W. Song (Ed.), China's Relations with Central and Eastern Europe: From" old Comrades" to New Partners. Oxon: Routledge.

Nelaeva, G. A., \& Semenov, A. V. (2016). EU-Russia rivalry in the Balkans: Linkage, leverage and competition (the case of Serbia). Romanian Journal of European Affairs, 16, 56.

Noutcheva, G. (2009). Fake, partial and imposed compliance: the limits of the EU's normative power in the Western Balkans. Journal of European Public Policy, 16(7), 1065-1084.

Peel, M. (2018). Bulgaria to host contentious China summit. Financial Times.

Retrieved from https://www.ft.com/content/eodd5d3a-5aa1-11e8-bdb7f6677d2e1ce8.

Plevnik, J. (2016). The Belt and Road Initiative and its implications for Southeast Europe. Retrieved from Belgrade.

RCC. (2017). About Regional Cooperation Council. Retrieved from http://www.rcc.int/pages/2/about-us.

Song, W. (2018). China's Long March to Central and Eastern Europe. European Review, 26(4), 755-766.

Stanzel, A. (2016). China's Investment in Influence: the Future of 16+1 Cooperation. Retrieved from London: Szczudlik, J. (2018). Prospects for CEE-China Relations after the Sofia Summit. Retrieved from Warsaw.

Turrion, Ruth F. (2015). The EU approach to the Western Balkans: A security or political issue? Europolity: Continuity and Change in European Governance, 9(2), 11-27.

Tonchev, P. (2017). China's Road: into the Western Balkans. EUISS Policy Brief.

Tuszyński, R. (2015). Polish Perspectives on CEE-China 16+1 Cooperation: the Unexpected Ukrainian Factor. EUROPOLITY, 9(1), 189-220.

Tzifakis, N. (2007). EU's region-building and boundary-drawing policies: the European approach to the Southern Mediterranean and the Western Balkans. Journal of Southern Europe and the Balkans, 9(1), 47-64. 
Vangeli, A. (2016). Sino-Balkan Affairs in Times of Global Uncertainty. Retrieved from Zeneli, V. (2014). China's Balkan Gamble: Why is China investing so much in the debt-burdened Balkans? The Diplomat. 